\title{
Etika Penulisan Berita Korban Kejahatan Susila dan Anak Pelaku Kejahatan di Media Online
}

\author{
Eka Megawati ${ }^{1}$, Husen Mony ${ }^{2}$ \\ ${ }^{1}$ Prodi Ilmu Komunikasi, Sekolah Tinggi Ilmu Komunikasi Profesi, Jakarta, Indonesia \\ ${ }^{2}$ Fakultas Ilmu Komunikasi, Universitas Sahid, Jakarta, Indonesia
}

\begin{abstract}
ABSTRAK
Masalah penelitian ini adalah bagaimana pelanggaran etika jurnalistik terkait penulisan berita korban kejahatan susila dan pelaku kejahatan di bawah umur di media online. Tujuan penelitian ini untuk mengetahui bentuk pelanggaran di media online, terkait: Pertama, bentuk-bentuk penyebutan identitas korban kejahatan susila; Kedua, bentuk-bentuk penyebutan identitas anak pelaku kejahatan; Ketiga, wartawan yang melakukan pelanggaran penyebutan identitas. Metode penelitian ini adalah analisis isi kuantitatif (quantitative content analysis). Populasinya adalah media online nasional dan lokal. Hasil penelitian menunjukan bahwa bentuk-bentuk informasi identitas korban kejahatan susila seperti: penyebutan nama ayah (kandung/tiri) korban, penyebutan alamat rumah dan sekolah korban, serta informasi tentang kampung atau desa/dusun dari korban. Sedangkan informasi identitas anak pelaku kejahatan dalam berita muncul dalam bentuk foto jurnalistik yang menampilkan wajah pelaku (di bawah umur) secara jelas, serta nama pelaku. Dari 111 wartawan yang melanggar ketentun Pasal 5 Kode Etik Jurnalistik, dalam penulisan beritanya, sebanyak 13 yang sudah memiliki sertifikasi kompetensi dari Dewan Pers, 65 belum bersertifikat, 33 lainnya tidak terlacak karena menggunakan nama inisial. Simpulan penelitian ini adalah masih terjadi pelanggaran dalam penyebutan identitas korban susila dan anak pelaku tindak kejahatan di media online, yang bahkan telah terverifikasi Dewan Pers.
\end{abstract}

\begin{abstract}
The issue of this research is how journalistic ethics violations related to the writing of news victims of moral crimes and perpetrators of underage crimes in online media. The purpose of this study is to find out the form of violations in online media, related: First, the forms of mention of the identity of victims of moral crimes; Second, the forms of mention of the identity of the child abuser; Third, journalists who commit violations of the mention of identity. This research method is quantitative content analysis. The population is national and local online media. Hasil research shows that forms of information on the identity of victims of moral crimes such as: the mention of the name of the father (biological father/step father) of the victim, the mention of the victim's home and school address, as well as information about the village or village / hamlet of the victim. While the identity information of the child perpetrators in the news appears in the form of photojournalism that displays the face of the actor $u(m i n o r)$ clearly, as well as the name of the perpetrator. Of the 111 journalists who violated article 5 of the Journalistic Code of Ethics, in writing the news, as many as
\end{abstract}

KATA KUNCI media sosial; komunikasi; politik; Susi Pudjiastuti; ketahanan laut; Indonesia

KEYWORDS Journalistic ethics; Moral Victims; Child; Normative Theory 
13 who already have competency certification from the Press Council, 65 have not been certified, 33 others are not tracked because they use initial names. The conclusion of this research is that there are still violations in the mention of the identity of moral victims and children of perpetrators of crimes in online media, which has even been verified by the Press Council.

\section{PENDAHULUAN}

Pasal 5 (lima) Kode Etik Jurnalistik (KEJ) menyebutkan "Wartawan Indonesia tidak menyebutkan dan menyiarkan identitas korban kejahatan susila dan identitas anak yang menjadi pelaku kejahatan." Dalam penjelasannya, identitas korban kejahatan susila yang dimaksud berkenaan dengan segala informasi yang memungkinkan diketahuinya korban tersebut oleh orang lain. Sedangkan definisi anak adalah seorang yang berusia kurang dari 16 tahun dan belum menikah. Keberadaan aturan tersebut dimaksudkan untuk melindungi korban kejahatan susila dari kemungkinan adanya ekses lanjutan dalam interkasi sosialnya di masyarakat. Dalam prakteknya, masih dijumpai adanya berbagai bentuk eksposur identitas korban kejahatan susila oleh media massa. Identitas yang kerap diekspos oleh media seperti penyebutan nama orang tua, domisili, pekerjaan, foto atau gambar diri orang terdekat korban atau pun korban itu sendiri.

Pemberitaan tentang pemerkosaan yang dilakukan ayah kandung terhadap putrinya di Lumajang oleh beberapa media online saat ini, dapat diidentifikasi sebagai pelanggaran etika. Dalam berita berjudul "Pria Setubuhi Anaknya di Lumajang Babak Belur Dipukuli Sesama Tahanan", Kumparan.com (berita dimuat pada Kamis, 01 Agustus 2019, pukul 14.01 WIB) tidak hanya menyebutkan nama pelaku (yang adalah ayah korban) tetapi juga menampilkan wajah pelaku secara terang, tanpa ditutup-tutupi, dalam foto jurnalistik yang dipublis bersamaan dengan artikel beritanya. Padahal baik nama pelaku maupun foto wajah pelaku, adalah identitas yang mesti disembunyikan untuk melindungi korban.

Media juga kerap melanggar dalam pemberitaan tentang anak yang menjadi pelaku kejahatan. Kasus kecelakaan yang menyebabkan hilangnya nyawa dimana pelakunya adalah anak Ahmad Dani, Abdul Jaelani (Dul), identitas anak tersebut disekspose secara terang ke publik. Padahal, usianya saat itu masih di bawah 16 tahun. Secara etika jurnalistik media wajib melindungi identitasnya. (Sudibyo, 2013, p. 11).

Kasus lain, terkait pemukulan terhadap siswi SMP berinisial AU (14 tahun) yang dilakukan oleh sejumlah siswi SMU di Pontianak. Meskipun usia rata-rata para pelaku yang melakukan pemukulan tersebut masih di bawah umur, media tetap saja memberitakan informasi yang dapat dikategorikan sebagai identitas, seperti nama dan alamat sekolah, nama orang tua, dan bahkan wajah mereka juga dimuat secara terbuka. Pelanggaran tersebut tidak hanya dilakukan oleh wartawan pemula atau pun media 
pemberitaan online yang masuk kategori biasa, tapi juga dilakukan oleh wartawan senior (bahkan yang sudah tersertifikasi Dewan Pers) serta media-media besar.

Menurut Johnson (dalam Madonna, 2020, p. 7), kasus-kasus yang terjadi dalam pemberitaan media online meliputi penyerangan kepentingan individu, pencemaran nama baik, pembunuhan karakter atau reputasi seseorang, penyebaran kebencian, rasial, dan mempertentangkan ajaran agama dan sebagainya. Selanjutya, Zamzuardi \& Syahrul (2019, p. 51) dalam penelitiannya menemukan bahwa berita tentang kejahatan seksual di media cenderung melemahkan posisi korban (perempuan), meski terbukti adanya tindak kekerasan yang disebabkan oleh pelaku.

Penelitian ini bertujuan, antara lain mengetahui bentuk-bentuk pelanggaran penyebutan identitas korban kejahatan susila dalam berita; mengetahui bentuk-bentuk penyebutan identitas anak pelaku kejahatan dalam berita; dan mengetahui wartawan yang melanggar kode etik dalam penulisan berita. Tujuan lanjutnya adalah mengetahui lebih dalam apakah wartawan yang melakukan pelanggaran terkait Pasal 5 KEWI tersebut telah tersertifikasi di Dewan Pers atau belum.

Adapun manfaat secara akademis penelitian ini sebagai pengayaan pada studi ilmu jurnalistik, khususnya menyangkut bahasa jurnalistik dalam aspek hukum dan etika penulisan berita. Sedangkan secara praktis, penelitian ini diharapkan dapat mendorong tumbunya kesadaran hukum dan etika pers pada seluruh wartawan, dan sekaligus mendorong tumbuhnya jurnalisme yang sensitif terhadap korban dan masalah kejahatan susila di Indonesia, yang marak terjadi belakangan ini.

\section{METODOLOGI PENELITIAN}

Penelitian ini mengunakan analisis isi kuantitatif (quantitative content analysis). Analisis isi merupakan metode penelitian yang berupaya menganalisis isi teks (konten) yang terdapat dalam sebuah medium komunikasi (Neuman, 2013, p. 400). Secara aplikatif, metode ini digunakan untuk menganalisis pelanggaran penyebutan dan penyiaran berita mengenai identitas korban kejahatan susila dan pelaku kejahatan di bawah umur oleh media online. Fokus pengamatan terhadap kata, kalimat, gambar, foto, video, dan audio serta konteks berita. Populasi penelitian ini adalah media online resmi yang tercatat di Dewan Pers, yaitu 10 media online nasional dan 46 media online lokal. Penarikan sampel media online lokal secara purposif, dengan kriteria: (1) memiliki badan hukum yang sah; (2) terdaftar di Dewan Pers (telah terverifikasi secara administrasi dan faktual); (3) memiliki susunan redaksi yang jelas; (4) Mengumumkan secara terbuka kepada publik; dan (5) melaksanakan kegiatan jurnalistik selama minimal 1 (satu) tahun. 


\section{HASIL DAN PEMBAHASAN}

\section{Media Online Nasional \& Pelanggaran Penulisan Identitas Korban Kejahatan Susila}

Dalam pemberitaan mengenai "korban kejahatan susila", sebagaimana diatur dalam Pasal 5 Kode Etik Wartawan Indonesia (KEWI), berbunyi: "Wartawan Indonesia tidak menyebutkan dan menyiarkan identitas korban kejahatan susila dan identitas anak yang menjadi pelaku kejahatan", pada 10 media online nasional, diperoleh temuan seperti tersaji dalam data-data berikut:

Tabel 1. Penyebutan Identitas "Korban Kejahatan Susila” di Okezone.com

\begin{tabular}{ccc}
\hline Jumlah artikel & Jumlah pelanggaran & persentase \\
\hline 29 & 7 & $24 \%$ \\
\hline
\end{tabular}

Dari 29 artikel berita yang dimuat oleh Okezone.com, pelanggaran terhadap etik penulisan, ditemukan dalam 7 (24\%) berita. Pelanggaran tersebut hadir dalam berbagai bentuk informasi identitas, seperti: penyebutaan nama dan alamat sekolah korban, penyebutan nama orang tua korban, dan penyebutan desa atau kampung dimana korban tinggal dan menetap bersama keluarganya.

Tabel 2. Penyebutan “Identitas Korban Kejahatan Susila” di Tribunnews.com

\begin{tabular}{ccc}
\hline Jumlah artikel & Jumlah pelanggaran & persentase \\
\hline 50 & 5 & $10 \%$ \\
\hline
\end{tabular}

Dari 50 artikel berita yang disajikan oleh Tribunnews.com, pelanggaran terhadap etika penulisan, ditemukan dalam 5 (10\%) berita. Pelanggaran tersebut hadir dalam berbagai bentuk informasi identitas, seperti: penyebutan nama kampung atau desa, penyebutan nama korban, pemuatan foto yang menampilkan wajah korban dengan jelas, penyebutan alamat rumah, dan penyebutan identitas orang tua (ibu kandung) korban.

Tabel 3. Penyebutan “Identitas Korban Kejahatan Susila” di Detik.com

\begin{tabular}{ccc}
\hline Jumlah artikel & Jumlah pelanggaran & persentase \\
\hline & & \\
200 & 6 & $3 \%$ \\
\hline
\end{tabular}

Dari 200 artikel berita yang disajikan oleh Detik.com, pelanggaran terhadap etika penulisan, ditemukan dalam $6(3 \%)$ berita. Pelanggaran tersebut hadir dalam berbagai bentuk informasi identitas, seperti: penyebutan nama ayah korban, yang dalam hal ini bertindak sebagai pelaku perbuatan asusila kepada anaknya sendiri. Selain itu juga penyebutan nama desa atau kampung korban, serta pemuatan foto jurnalistik yang menampilkan wajah korban dengan jelas. 
Tabel 4. Penyebutan "Identitas Korban Kejahatan Susila" di Sindonews.com

\begin{tabular}{ccc}
\hline Jumlah artikel & Jumlah pelanggaran & persentase \\
\hline 182 & 8 & $4.4 \%$ \\
\hline
\end{tabular}

Dari 182 artikel berita yang disajikan oleh Sindonews.com, pelanggaran terhadap etika penulisan, ditemukan dalam 8 (4.4\%) berita. Pelanggaran tersebut hadir dalam berbagai bentuk informasi identitas, seperti: penyebutan nama asli korban, penyebutan nama ibu kandung korban, alamat rumah korban, dan nama ayah kandung korban, yang dalam hal ini bertindak sebagai pelaku asusila terhadap korban (anak kandung sendiri).

Tabel 5: Penyebutan "Identitas Korban Kejahatan Susila” di Kompas.com

\begin{tabular}{ccc}
\hline Jumlah artikel & Jumlah pelanggaran & persentase \\
\hline & & \\
145 & 3 & $2.1 \%$ \\
\hline
\end{tabular}

Dari 145 artikel berita yang disajikan oleh Kompas.com, pelanggaran terhadap etika penulisan, ditemukan dalam $3(2.1 \%)$ berita. Pelanggaran tersebut hadir dalam berbagai bentuk informasi identitas, seperti: penyebutan dusun atau kampung korban dan foto dari suami korban kejahatan susila (dalam berita ini, suaminya ditetapkan sebagai tersangka pembunuhan terhadap pria yang memperkosa isterinya).

Tabel 6: Penyebutan “Identitas Korban Kejahatan Susila” di Liputan6.com

\begin{tabular}{ccc}
\hline Jumlah artikel & Jumlah pelanggaran & persentase \\
\hline & & \\
18 & 2 & $11.1 \%$ \\
\hline
\end{tabular}

Dari 18 artikel berita yang disajikan oleh Liputan6.com, pelanggaran terhadap etika penulisan, ditemukan dalam $2(11.1 \%)$ berita. Pelanggaran tersebut hadir dalam berbagai bentuk informasi identitas, seperti: penyebutan nama korban dan nama desanya, serta nama orang tua (ayah) korban.

Tabel 7: Penyebutan “Identitas Korban Kejahatan Susila” di Kumparan.com Jumlah artikel Jumlah pelanggaran persentase

$55 \quad 5 \quad 9.1 \%$

Dari 55 artikel berita yang disajikan oleh Kumparan.com, pelanggaran terhadap etika penulisan, ditemukan dalam $2(11.1 \%)$ berita. Pelanggaran tersebut hadir dalam berbagai bentuk informasi identitas, seperti: penyebutan nama sekolah korban, nama desa korban, dan nama asli korban. 
Tabel 8: Penyebutan “Identitas Korban Kejahatan Susila” di Merdeka.com

\begin{tabular}{ccc}
\hline Jumlah artikel & Jumlah pelanggaran & persentase \\
\hline 93 & 6 & $6.5 \%$ \\
\hline
\end{tabular}

Dari 93 artikel berita yang disajikan oleh Merdeka.com, pelanggaran terhadap etika penulisan, ditemukan dalam 6 (6.5\%) berita. Pelanggaran tersebut hadir dalam berbagai bentuk informasi identitas, seperti: pemuatan foto yang menunjukan ayah korban, penyebutan alamat rumah korban, dan penyebutan nama asli ayah korban. Dalam hal ini, sebagian besar kasus kejahatan susila tersebut dilakukan oleh ayah kandung korban sendiri.

Tabel 9: Penyebutan “Identitas Korban Kejahatan Susila” di Cnnindonesia.com

\begin{tabular}{ccc}
\hline Jumlah artikel & Jumlah pelanggaran & persentase \\
\hline 20 & 2 & $10 \%$ \\
\hline
\end{tabular}

Dari 20 artikel berita yang disajikan oleh Cnnindonesia.com, pelanggaran terhadap etika penulisan, ditemukan dalam 2 (10\%) berita. Pelanggaran tersebut hadir dalam berbagai bentuk informasi identitas, seperti: penyebutan nama sekolah korban, dan penyebutan nama asli ayah korban, yang dalam peristiwa tersebut bertindak sebagai pelaku kejahatan susila terhadap korban, anak kandung sendiri.

Dalam penelitin ini, meskipun Suara.com menyajikan sebanyak 86 artikel berita yang memuat tentang tindak asusila, tidak ditemukan adanya pelanggaran etika pada penulisan berita tersebut. Tapi, sebagaimana beberapa media online yang lain seperti Kompas.com, Tribunnews.com, dan Merdeka.com, hasil pencarian artikel berita yang memuat masalah penelitian ini menyajikan data yang sedikit. Hal ini karena media-media tersebut bekerjasama dengan Google.com. Data yang tim peneliti peroleh didasarkan pada hasil sajian dari Google, yang memang terbatas. Dugaan kami, banyak artikel berita yang memuat masalah penelitian pada, tahun 2019, tidak dimunculkan oleh Suara.com (dan media online lain di atas). Sehingga peluang akan munculnya artikel berita yang melanggar "penyebutan identitas korban susila", sangat mungkin ada.

Penelitian ini juga menemukan bahwa dari 44 kasus pelanggaran terhadap Pasal 5 Kode Etik Jurnalistik, bentuk informasi terkait “Identitas Korban Kejahatan Susila” yang sering disebutkan dalam pemberitaan seperti, nama asli korban (serta wajahnya ditampilkan dalam foto jurnalistik), nama orang tua korban (termasuk di dalamnya wajah mereka yang disajikan dalam foto jurnalistik), alamat rumah korban, nama desa, dusun, atau kampung korban, alamat rumah, dan nama (serta alamat) sekolah korban.

Bentuk informasi identitas korban kejahatan susila yang paling banyak ditulis dalam pemberitaan media online nasional adalah nama asli ayah dan ibu kandung korban, yakni 
sebanyak 18 kali. Berikutnya, informasi yang mengarah kepada nama kampung, dusun, atau desa/kelurahan dari para korban. Berdasarkan hasil penelusuran terhadap artikelartikel berita tersebut, ditemukan bahwa informasi terbanyak adalah tentang nama ayah kandung. Hal ini karena, sekitar 50 persen kasus-kasus perbuatan asusila tersebut dilakukan oleh ayah kandungnya sendiri. Dugaan peneliti, besar kemungkinan bahwa para wartawan yang menulis berita dengan peristiwa yang melibatkan ayah sebagai pelaku kejaahatan susila tersebut, marah atau emosional. Sehingga ayah tidak dipandang sebagai sebuah "identitas" bagi anak, yang dalam hal ini adalah korban kejahatan susila. Temuan lain yang juga tinggi berkaitan dengan penyebutan informasi nama kampung, dusun, atau desa dimana korban tinggal dann menetap yang. Kampung, dusun, atau desa menjadi identitas bagi korban karena berada dalam wilayah yang secara kultur, masyarakatnya saling mengenal satu sama lain dengan baik.

\section{Media Online Lokal \& Pelanggaran Penulisan Identitas Korban Kejahatan Susila}

Penelitian pelanggaran penulisan identitas "Korban Kejahatan Susila", sebagaimana tercantum dalam Pasal 5 Kode Etik Jurnalistik, dilaksanakan dengan meneliti sejumlah media lokal dari 36 Provinsi yang ada di Indonesia. Dalam hal ini, kriteria media lokal yang ditetapkan oleh peneliti adalah perusahaan Pers yang sudah tercatat atau terverifikasi di Dewan Pers. Masing-masing media ditentukan sebanyak 1-3 sampel media lokal. Dari 36 Provinsi yang ada di Indonesia, terdapat 3 Provinsi yang media lokalnya tidak tercatat atau belum terverifikasi oleh Dewan Pers, diantaranya: Nusa Tenggara Timur, Papua, dan Papua Barat.

Dari 31 provinsi terdapat 59 media online yang diteliti, diperoleh hasil bahwa dari sebanyak 638 artikel berita yang memuat informasi tentang "Korban Kejahatan Susila" (dalam bentuk perkosaan, pelecehan, pencabulan, upaya perkosaan, dan sebagainya), terdapat 59 artikel yang melanggar ketentuan Pasal 5 Kode Etik Jurnalistik.

Eksposur terhadap informasi yang berkaitan dengan identitas "korban kejahatan seksual" dalam berita media online lokal, hadir dalam bentuk penyebutan identitas berupa: (1) pemuatan foto atau wajah korban maupun pelaku (orang tuanya sendiri) dalam foto jurnalistik; (2) nama lengkap ayah (kandung maupun tiri) yang dalam hal ini bertindak sebagai pelaku pemerkosaan; (3) nama desa, kampung, kelurahan, atau dusun, serta alamat rumah korban; (4) nama sekolah; (5) nama lengkap keluarga lain (sebagai pelaku), seperti nama lengkap kakek.

Informasi tentang nama desa, kampung, kelurahan, atau dusun, serta informasi alamat rumah (nama jalan dan RT/RW), menempati urutan pertama, sebagai identitas korban kejahatan susila yang paling banyak diekspos oleh media online lokal (sebanyak 45 berita/kasus). Selanjutnya informasi mengenai nama ayah (baik ayah tiri maupun ayah kandung) korban, yang dalam hal ini bertindak sebagai pelaku pemerkosaan itu sendiri (sebanyak 18 berita/kasus). Untuk identitas mengenai nama lengkap ayah korban, menempati posisi kedua dalam pemberitaan media lokal. Selanjutnya foto/wajah dari 
pelaku (sebanyak 9 berita/kasus) yang merupakan keluarga terdekat korban (ayah kandung, ayah tiri, ibu kandung, kakek, atau paman). Selanjutnya informasi mengenai nama sekolah korban (sebanyak 3 berita/kasus). Penyebutan identitas berupa nama sekolah korban biasanya terjadi pada peristiwa yang melibatkan pihak sekolah sebagai pelaku kejahatan susila terhadap muridnya sendiri.

\section{Media Online Nasional \& Pelanggaran Penulisan Identitas Anak Pelaku Kejahatan}

Anak pelaku tindak kejahatan merupakan individu yang harus dilindungi oleh media atau wartawan dalam pemberitaannya. Dalam hal ini, sebagaimana tercantum dalam Pasal 5 kode etik jurnalistik. Upaya perlindungan terhadap anak (meskipun sebagai pelaku suatu tindak kejahatan) merupakan bagaian tak terpisahkan juga dari perintah UU No. 23 Tahun 2002 sebagaimana telah dirubah menjadi UU No. 35 Tahun 2014 tentang Perlindungan Anak. Dalam pertimbangannya, regulasi tentang anak tersebut menjelaskan bahwa perlindungan terhadap anak didasari atas 2 hal, yaitu: (1) anak memiliki hak kelangsungan hidup, tumbuh dan berkembang; (2) sebagai tunas, potensi, atau generasi muda yang akan melanjutkan perjuangan dan cita-cita bangsa.

Dari analisis terhadap artikel berita yang memuat informasi tentang identitas "Anak Pelaku Kejahatan" sebagaimana juga diatur dalam Pasal 5 KEWI, diperoleh data temuan sebagai berikut:

Tabel 10: Penyebutan “Identitas Anak Pelaku Kejahatan” di Detik.com

Jumlah artikel Jumlah pelanggaran persentase

\begin{tabular}{lll}
156 & 4 & $2.7 \%$ \\
\hline
\end{tabular}

Dari 156 artikel berita yang disajikan oleh Detik.com, pelanggaran terhadap etika penulisan, ditemukan dalam 4 (2.7\%) berita. Pelanggaran tersebut hadir dalam beberapa bentuk informasi identitas, seperti: menampilkan foto anak pelaku kejahatan yang memperlihatkan wajahnya dengan jelas, dan penyebutan nama kampung.

Tabel 11: Penyebutan “Identitas Anak Pelaku Kejahatan” di Kumparan.com

\begin{tabular}{ccc}
\hline Jumlah artikel & Jumlah pelanggaran & persentase \\
\hline 33 & 1 & $3 \%$
\end{tabular}

Dari 33 artikel berita yang disajikan oleh Kumparan.com, pelanggaran terhadap etika penulisan, ditemukan dalam 1 (3\%) berita. Pelanggaran tersebut hadir dalam bentuk penyajian foto pelaku (anak di bawah umur), sehingga menampilkan wajahnya secara jelas kepada pembaca. 
Tabel 12: Penyebutan "Identitas Anak Pelaku Kejahatan" di Merdeka.com

\begin{tabular}{ccc}
\hline Jumlah artikel & Jumlah pelanggaran & persentase \\
\hline 44 & 2 & $4.5 \%$ \\
\hline
\end{tabular}

Dari 44 artikel berita yang disajikan oleh Merdeka.com, pelanggaran terhadap etika penulisan, ditemukan dalam $2(4.5 \%)$ berita. Pelanggaran tersebut hadir dalam bentuk penyajian informasi identitas berupa penyebutan nama asli pelaku (anak) dan pemuatan foto jurnalistik yang menampilkan wajah asli anak pelaku kejahatan tersebut.

Tujuh dari 10 media online yang diteliti, diantarannya Okezone.com, Sindonews.com, Tribunnews.com, Kompas.com, Suara.com, Liputan6.com, dan CNNIndonesia.com, tidak ada temuan terkait pelanggaran Pasal 5, kaitannnya dengan penyebutan "Identitas Anak Pelaku Kejahatan". Dengan kata lain, ketujuh media tersebut menerapkan prinsip penulisan yang sesuai dengan standar etika jurnalistik, dalam peristiwa yang berkaitan dengan tindak kejahatan yang dilakukan oleh anak di bawah umur, seperti pembunuhan, tawuran, begal, perundungan, perampokan, pemerkosaan dan pelecehan seksual, narkoba, video asusila, dan lain-lain.

Tabel 13: Bentuk Penyebutan Identitas “Anak Pelaku Kejahatan” di media online Nasional

\begin{tabular}{lll}
\hline No & $\begin{array}{l}\text { Bentuk Penyebutan Informasi } \\
\text { Identitas Anak Pelaku Kejahatan }\end{array}$ & f \\
\hline 1. & Nama asli pelaku & 2 \\
\hline 2. & Foto/wajah pelaku & 5 \\
\hline
\end{tabular}

Dari 10 media online nasional - hanya 3 media memiliki temuan - yang diteliti mengenai penyebutan informasi yang berkaitan dengan identitas anak pelaku kejahatan, pada berita tentang kejahatan yang melibatkan anak di bawah umur, bentuk identitas yang tersebut yaitu: foto jurnalistik yang menampilkan wajah pelaku dengan jelas sebanyak 5 kali, dan penyebutan nama asli korban sebanyak 2 kali.

\section{Media Online Lokal \& Pelanggaran Penulisan Identitas Anak Pelaku Kejahatan}

Dari 178 artikel berita yang berisi informasi tentang peristiwa yang melibatkan anak sebagai pelaku tindak kejahatan, diperoleh sebanyak 25 temuan yang berisi informasi yang berkaitan dengan identitas pelaku di bawah umur. Adapun informasi yang berupa identitas "anak pelaku tindak kejahatan", yang tersaji dalam pemberitaan media online seperti: (1) nama lengkap para pelaku di bawah umur itu sendiri; (2) menampilkan foto yang memperlihatkan wajah pelaku/para pelaku; (3) menampilkan wajah orang tua pelaku (ibu kandung); (4) informasi mengenai nama desa, kampung, keluruhan, atau nama dusun dimana pelaku tinggal, disertai juga dengan informasi nama jalan dan RT/RW rumah pelaku; dan (5) nama dan alamat sekolah pelaku. 
Informasi mengenai nama desa, kampung, kelurahan, dusun, atau secara spesifik menyebutkan nama jalan dan RT/RW dimana pelaku (anak di bawah umur) itu tinggal, berada di urutan pertama pelanggaran pemberitaan yang dilakukan oleh media online lokal, dengan 17 kasus. Selanjutnya, pada urutan kedua informasi tentang nama lengkap pelaku (8 kasus), serta diikuti dengan menampilkan wajah (yang meskipun bagian mataya ditutup) yang dapat dikenali oleh pembaca, menempati urutan ketiga (7 kasus). Informasi tentang nama sekolah pelaku (2 kasus), dan nama lengkap ibu pelaku (1 kasus).

\section{Diskusi}

\section{Ayah sebagai Pelaku Pemerkosaan: Identitas Korban}

Identitas sebagaimana penjelasan Pasal 5 KEWI adalah semua data dan informasi yang menyangkut diri seseorang yang memudahkan orang lain untuk melacak. Penyebutan nama kampung, nama orang tua korban, nama sekolah korban, apalagi nama asli korban adalah berbagai informasi yang memudahkan orang lain melacak keberadaan korban tersebut (Sudibyo, 2013, p. 10). Definisi tersebut menggunakan istilah "melacak", dimana berdasarkan pencarian makna melalui (KBBI Daring, 2020) memiliki makna mencari atau menuruti jejak; memeriksa dengan teliti; menyelidiki, dengan kata lain artinya berbagai informasi tersebut di atas berkemungkinan untuk ditelusuri oleh pihak lain, dalam rangka mengetahui identitas korban. Etika jurnalistik dihadirkan dalam rangka untuk menjaga penggunaan informasi tersebut oleh pihak yang tidak bertanggung jawab. Hal ini tentu saja selain untuk melindungi berbagai kepentingn (utamanya korban dan media itu sendiri).

Media dan korban (serta pembaca) terlibat dalam interkasi melalui teks pemberitaan. Dalam hal ini, media sebagai produsen teks, korban sebagai subjek-objek teks, dan pembaca sebagai konsumen. Dalam interaksi yang terjalin, media massa sebagai pordusen teks memiliki tanggung jawab utuk memastikan bahwa pesan yang termuat di dalamnya baik atau buruk (dalam konteks moralitas). Sebab, tindakan komunikasi yang dilakukan media berkaitan dengan pihak lain, dalam konteks sosial (Mustofa, 2012). Media tidaklah hidup di ruang hampa, oleh karenanya wajib memikirkan dampak tindakan komunikasi yang diperbuatnya tersebut kepada pihak lain.

Penyebutan identitas ayah korban, banyak menjadi temuan dalam penelitian ini. Wartawan menulis dengan jelas nama ayah atau menampilkan dengan terang wajah ayah korban melalui foto jurnalistitik. Penyebutan identitas ayah dari korban tersebut muncul dalam berbagai peristiwa tindak kejahatan susila yang dilakukan oleh ayahnya sendiri/ayah kandung atau ayah tiri. Dalam hal ini, ayah korban adalah sekaligus pelaku dalam pemerkosaan, dugaan pelecehan, atau tindak asusila lain terhadap anak kandungnya sendiri. Sebagain besar dari pelanggaran penulisan identitas di media online nasional, terkait dengan peristiwa seperti itu. Temuan penelitian memperlihatkan bahwa penyebutan nama ayah (kandung maupun tiri) berada dalam urutan kedua. 
Memang, dapat dipahami bahwa wartawan yang menulis peristiwa-peristiwa tersebut pasti diliputi dengan amarah yang besar terhadap pelaku, yang tega memperkosa anaknya sendiri. Dalam keseharian kehidupan, kita sering mendengar peribahasa "Harimau saja tidak akan memakan anaknya sendiri". Tindakan ayah kandung yang memperkosa anaknya sendiri adalah perbuatan amoral. Hal inilah yang mendorong wartawan meluapkan emosi dan amarahnya dalam bentuk teks, dengan tujuan untuk mempermalukan pelaku.

Dalam memberitakan peristiwa pemerkosaan atau pelecehan seksual, media online, sebagaimana temuan kami dalam penelitian ini mengungkap berbagai identitas korban. Hal ini tentu saja sangat melemahkan posisi perempuan, dalam hal ini sebagai korban kejahatan seksual. Perempuan korban kejahatan seksual, dalam teks pemberitaan media online sering berada dalam situasi seperti pribahasa "sudah jatuh tertimpa tangga pula". Zamzuardi \& Syahrul (2019, p. 51) dalam penelitiannya mengemukakan bahwa berita tentang kejahatan seksual di media cenderung melemahkan posisi korban (perempuan), meski terbukti adanya tindak kekerasan yang disebabkan oleh pelaku.

Pelaku, yang notabene adalah pria sering berada dalam situasi yang diuntungkan dalam teks berita. Dalam hal ini, media sering memperhalus peristiwa kekerasan dengan diksidiksi yang tidak mencerminkan rasa keadilan kepada korban. Misanya, dalam berbagai peristiwa pemerkosaan, wartawan sering menggunakan diksi-diksi seperti digagahi, dilecehkan, dirudapaksa, mesum, dan sebagainya.

Hasil kajian Komnas Perempuan terhadap teks berita media mengenai kasus kekerasan seksual mengkonfirmasi bahwa korban kadang disudutkan. Istilah yang digunakan Komnas Perempuan adalah perempuan yang mengalami kekarasan seksual kembali "diperkosa oleh media” demi menaikan jumlah pembaca. Strategi yang dilakukan oleh media melalui penulisan diski yang memperhalus peristiwa yang dialami (dan nantinya diderita seumur hidup oleh korban). Diksi-diksi seperti mesum, lecehkan, digagahi, dan lainnya dimaknai bahwa penulis (wartawan) tidak memiliki empati terhadap nasib dan penderitaan korban (Komnas Perempuan, 2014, dalam Susilo, 2017). Studi yang dilakukan Setiawan (2011) menjelaskan juga bahwa secara tekstual berita mengenai kekerasan terhadap perempuan, seperti halnya peristiwa kekerasan seksual, cenderung menunjukan bias gender, seperti misalnya dengan penggunaan kata-kata oleh jurnalis, seperti 'dipaksa', 'digilir', 'digarap', 'tergiur', 'mendapat jatah mengerjai korban', 'gadis berparas ayu', dan lain-lain.

Mendukung pandangan dua temuan di atas tersebut, Christiany Judith dalam (Elisabeth \& Dewi, 2019) bahwa perempuan dalam pemberitaan media massa sering mendapatkan kerugian. Dia menyoroti masalah tersebut dari perspektif ruang redaksinya. Sebagian besar media massa dikuasi oleh pria, mulai dari fotografer, wartawan, editor, layouter, dewan redaksi. Hal ini membuat pemberitaan tentang peristiwa kejahatan susila cenderung bias gender ke laki-laki. 


\section{Alamat Tinggal sebagai Identitas Utama Terekspose dalam Berita}

Dari temuan yang ada, diperoleh bahwa informasi mengenai alamat tempat tinggal korban atau pun pelaku dibawah umur, yang hadir melalui penulisan nama desa, kampung, kelurahan, dusun, atau pun secara spesifik nama jalan, gang, dan RT/RW (disertai dengan informasi nama kampung, kecaamatan, dan kabupaten/kota), merupakan informasi identitas yang berada pada urutan pertama, sering disebut dalam teks pemberitaan media online nasional maupun lokal. Informasi yang dimaksud tidak hanya pada pemberitaan mengenai "anak pelaku tindak kejahatan" tetapi juga pada peristiwa mengenai "korban kejahatan seksual”.

Umumnya, berdasarkan temuan penelitian ini, dalam berita mengenai peristiwa yang melibatkan anak sebagai pelaku tindak kejahatan, informasi mengenai tempat tinggal (desa, kampung, dusun, nama jalan, dan sebagainya), biasanya dilekatkan langsung oleh wartawan diakhir penyebutan nama atau inisial pelaku. Misalnya, dalam berita berjudul: Tiga Pelajar Diduga Pelaku Curas Ditangkap Tim Buser Polres Inhil, sebagaimana dimuat dalam kilasriau.com (Senin, 07 Januari 2019). Informasi mengenai alamat tempat tinggal para pelaku tersebut ditulis wartawan, seperti berikut:

"Adapun ketiga teraangka yang yelah ditangkap tersebut yakni masing-masing berinisial "PS" (16) Warga jl. Datuk Bandar, "MA" (15) Warga Jl P. Hidayat dan "RF" (16) Warga Jl. Gunung Daek"

Untuk peristiwa yang berkaitan dengan pemerkosaan, informasi yang menunjukan tempat tinggal korban memang tidak secara spesifik ditulis sebagai keterangan lanjut setelah nama korban (baik berupa nama samaran maupun inisial). Biasanya informasi tersebut hadir melalui penjelasan keterangan alamat tinggal dari pelaku tindak kejahatan asusila tersebut. Oleh karena pelaku perbuatan tindak kejahatan susila adalah orang terdekat korban (ayah kandung, ayah tiri, kakek, paman, saudara laki-laki, dan sebagainya), maka dengaan mudah pembaca akan mengetahui alamat tinggal korban. Terlebih lagi, penyebutan alamat tinggal pelaku tersebut kerap diikuti dengan informasi "pelengkap" lain, seperti: "tinggal bersama”, "dirumahnya sendiri”, "saat ibunya sedang keluar", "ayahnya masuk ke kamar anaknya”, "masih tetangga”, "tinggal tidak jauh", "rumahnya tidak jauh", dan sebagainya.

Strategi penulisan demikian, selain karena problem kompetensi wartawan dan ketidakpatuhan terhadap etika jurnalistik yang berlaku (mungkin juga tidak tau), patut diduga juga arena rasa marah dan keinginan wartawan untuk mempermalukan pelaku. Ini sejalan juga dengan adanya temuan dimana wartawan menyebutkan nama lengkap serta memuat foto (terlihat wajah dengan jelas) pelaku, yang tak lain adalah ayah atau kerabat terdekat korban. Juga pada berita tentang pelaku tindak kejahatan, yang meski masih di bawah umur, tetapi karena keinginan mempermalukan pelaku tersebut, maka disebutkan informasi mengenai alat tinggalnya. 
Informasi tentang identitas "korban kejahatan susila" maupun "anak pelaku tindak kejahatan", pada prinsipnya sama saja, yaitu berkaitan dengan segala indentitas yang memungkinkan orang atau pihak lain mengetahui siapa diri mereka. Mahendra \& Harefa (2020) mengurai jawaban dari ketua Dewan Pers, berkaitan dengan informasi yang dapat digolongkan sebagai identitas anak, seperti: nama, foto, gambar, nama kakak atau adik, orang tua, paman atau bibi, kakek atau nenek, dan tidak menyebut keterangan pendukung seperti alamat rumah, alamat desa, sekolah, perkumpulan atau klub, yang diikuti, dan benda-benda khusus yang merincikan sang anak.

Informasi mengenai alamat rumah atau tempat tinggal (desa, kampung, dusun, dan yang sejenisnya) juga ditetapkan sebagai identitas anak pelaku tindak kejahatan, sebagaimana tercantum dalam Peraturan Dewan Pers No. 1 Tahun 2019 tentang Pedoman Pemberitaan Ramah Anak. Peraturan tersebut menjadikan UU Perlindungan Anak dan Kode Etik Jurnalistik sebagai landasan hukumnya.

\section{Wartawan dan Kompetensi Penulisan Berita}

Berdasarkan keputusan Dewan Pers, ada 3 kompetensi dasar yang perlu dimiliki oleh seorang wartawan, yaitu: pengetahuan, keterampilan, dan kesadaran hukum-etika (Wijaya \& Yudiningrum, 2016). Keterampilan serta kesadaran hukum dan etika menjadi dua kompetensi yang memiliki relevansi dengan masalah penelitian ini. Keterampilan (skill) berkenaan dengan kemampuan wartawan dalam memilih dan menyusun kata atau diksi, kalimat, serta paragraf dalam merangkai sebuah peristiwa menjadi berita. Selain keterampilan mengoperasikan alat (Kamera, foto, editing, dan sebagainya). Sedangkan kesadaran hukum dan etika berkaitan dengan kepatuhan wartawan dalam menerapkan prinsip-prinsip etika dan hukum Pers di Indonesia, dalam kegiatan jurnalistik yang dilakukan, termasuk pada tahapan penulisan dan penyajian berita di media online. Untuk diakui sebagai wartawan berkompeten, maka Dewan Pers mencanangkan agar setiap wartawan mengikuti Standar Kompetensi Wartawan (SKW), dimana ketiga standar di atas akan dilatih dan diujikan kepada para peserta.

Dari 10 media online nasional yang diteliti, ditemukan sebanyak 47 wartawan yang melakukaan pelanggaran terhadap Pasal 5 KEWI. Dari 47 orang wartawan tersebut, sebanyak 43 (91.49\%) orang yang belum memiliki sertifikat kompetensi dari Dewan Pers, dan hanya 4 (8.51\%) wartawan yang telah memiliki sertifikat kompetensi dari Dewan Pers. Data tersebut, sebagaimana tersaji dalam tabel 14 berikut ini:

Tabel 14: Wartawan Media Online Nasional Bersertifikat Kompetensi

\begin{tabular}{lll}
\hline Kompetensi Wartawan & f & \% \\
\hline Bersertifikat kompetensi & 4 & 8.51 \\
\hline Tidak bersertifikat kompetensi & 43 & 91.49 \\
\hline Jumlah & $\mathbf{4 7}$ & $\mathbf{1 0 0 \%}$ \\
\hline
\end{tabular}

Sumber: Dewan Pers 
Dari tabel tersebut, dapat disimpulkan bahwa sebagian besar pelanggaran dalam hal etika penulisan terkait peristiwa korban kejahatan susila dan pelaku kejahatan di bawah umur, dilakukan oleh wartawan yang belum memiliki sertifikasi kompetensi, sebagaimana yang dikehendaki oleh negara melalui Dewan Pers.

Berikutnya, dari 59 media online lokal yang diteliti, dimana tersebar di 31 Provinsi di Indonesia, dari 64 wartawan yang penulisan beritanya melanggar Pasal 5 Kode Etik Jurnalistik, sebanyak 9 wartawan sudah memiliki sertifikat kompetensi. Sedangkan 22 orang wartawan lainnya tidak atau belum memiliki sertifikat kompetensi. Sisanya, sebanyak 33 wartawan tidak bisa dilacak status kompetensi mereka karena tidak menggunakan nama lengkap: nama pendek, inisial, atau inisial berupa angka.

Tabel 15. Wartawan Media Online Lokal Bersertifikat Kompetensi

\begin{tabular}{lcc}
\hline Kompetensi Wartawan & f & \% \\
\hline Bersertifikat kompetensi & 9 & $14.06 \%$ \\
\hline Tidak bersertifikat kompetensi & 22 & $34.38 \%$ \\
\hline Tidak terlacak & 33 & $51.56 \%$ \\
\hline Jumlah & 64 & $100 \%$ \\
\hline
\end{tabular}

\section{Struktur Berita dan Informasi Identitas}

Berita adalah laporan tentang peristiwa aktual yang terjadi ditengah masyarakat, dioalah oleh wartawan, dan kemudian disebarluaskan melalui media jurnalistik. Dalam konteks penelitian ini, media jurnalistik yang dipilih dalam penyebarluasan peristiwa tentang "korban kejahatan susila" dan "anak pelaku tindak kejahatan" adalah media online. Secara umum penulisan berita mengenai peristiwa "korban kejahatan susila" dan "anak pelaku tindak kejahatan", berdasarkan hasil penelitian ini, ditulis dengan menggunakan model pola piramida terbalik (inverted pyramid). Penulisan dengan menggunakan model piramida terbalik ini memiliki penjelasan bahwa bagian atau informasi yang paling penting ditempatkan pada awal paragraf, dan makin ke dalam, informasinya menjadi kurang penting (Mony, 2020).

Penulisan berita dengan menggunakan pendekatan piramida terbalik, memiliki struktur diantaranya judul, lead, body atau tubuh berita, dan penutup. Lead adalah bagian berita yang berisi informasi penting, yang menjadi jawaban media kepada pembaca atau pemirsa, terkait peristiwa atau isu yang sedang dipublikasikan. Informasi penting yang dimaksud kerap dikenal dengan istilah 5W+H. Suhandang (2016, dalam Bangun et al., 2019) mendefinisikan lead berita sebagai laporan singkat tentang peristiwa yang sedang dibahas, dan biasanya merupakan informasi klimaks. Body dan penutup berita sendiri merupakan elemen berita yang biasanya berisi informasi pengembangan dari lead.

Dalam penulisan berita dengan menggunakan model piramida terbalik, wartawan atau media menyadari bahwa lead biasanya berisi informasi penting yang harus segera diketahui oleh pembaca. Lead berisi informasi penting yang hendak dan ingin diketahui 
oleh pembaca terkait peristiwa atau isu yang sedang diberitakan. Dalam penulisan peristiwa tentang "korban kejahatan asusila" dan "anak pelaku tindak kejahatan" para wartawan media online terlihat dengan jelas menyadari pentingnya menghadirkan informasi penting dari peristiwa atau isu tersebut ke dalam lead. Jikapun dirasa tidak bisa disampaikan pada lead, maka body atau penutup berita adalah pilihan kesekian dalam pemaparan informasi terkait.

Hasil temuan penelitian ini menunjukan bahwa lead, selain berfungsi dalam penulisan informasi penting terkait peristiwa yang menjadi objek penelitian, pada bagian lead juga informasi tentang identitas yang seharusnya dilindungi, sebagaimana perintah Pasal 5 Kode Etik Jurnalistik dibuka oleh wartawan pada bagian itu. Pembaca yang membaca berita-berita tentang kedua peristiwa yang diteliti, dapat segera langsung menemukan atau mengetahui informasi terkait identitas dari korban kejahatan susila atau pun anak pelaku tindak kejahatan. Pembaca yang memiliki mobilitas tinggi (kerja, kuliah, atau sedang melaksanakan tugas-tugas lain), tidak perlu membaca berita sampai akhir. Cukup dengan membaca lead saja, sudah pasti informasi (tentang identitas korban susila dan pelaku anak) sudah dapat diketahui. Inilah yang menjadi salah satu alasan penulisan berita dengan pola piramida terbalik, dengan pengistimewaan bagian lead. (Mony, 2020).

Selain lead, body, dan penutup (yang merupakan informasi tekstual), bagian berita yang tidak kalah pentingnya adalah foto jurnalistik. Wilson Hick dalam (Fakhri \& Juanda, 2020) mendefinisikan foto jurnalistik sebagai media komunikasi dengan pendekatan elemen verbal dan visual. Verbal hadir dalam bentuk teks caption, sedangkan visual hadir dalam bentuk fotografi. Dalam ilmu jurnalistik, keberadaan foto jurnalistik tidak hanya berfungsi sebagai pelengkap atau pengayaan informasi beupa teks saja. Terkadang, foto jurnalistik mampu berbicara lebih banyak dan lebih nyata ketimbang narasi wartawan yang dituangkan dalam bentuk teks, tentang suatu peristiwa.

Temuan penelitian ini juga memperlihatkan bahwa foto jurnalistik yang disajikan pada peristiwa tentang korban kejahatan susila dan anak pelaku tindak kejahatan, secara signifikan juga melanggar Pasal 5 Kode Etik Jurnalistik. Dalam berita mengenai korban kejahatan susila, memang tidak ditemukan adanya foto jurnalistik yang secara vulgar mengungkap wajah korban, sehingga dapat diketahui pembaca. Temuan penelitian menunjukan foto jurnalistik kerap mengungkap pihak keluarga terdekat yang menjadi pelaku (atau turut melakukan) perbuatan asusila tersebut, seperti misalnya ayah kandung korban, ayah tiri korban, ibu kandung korban (biasanya bersama-sama dengan suaminya yang adalah ayah tiri korban), paman korban, kakek korban, atau saudara kandung/sepupu korban.

Sedangkan pada peristiwa terkait anak pelaku tindak kejahatan, pemuatan foto jurnalistik banyaknya mengekspos bagian wajah pelaku (yang masih di bawah umur). Sudut pengambilan fotonya adalah dari samping, atau sedang bersama-sama dengan para pelaku yang lain (sudah dewasa). Foto jurnalistik dalam peristiwa ini juga sering 
mengekspos wajah pelaku dari bagian depan, hanya bagian matanya saja yang diburamkan atau dicoret dengan warna hitam. Meski ada upaya menyembunyikan wajah pelaku tersebut, tetap saja dengan mudah pembaca bisa mengenal wajah pelaku yang merupakan anak di bawah umur tersebut.

\section{SIMPULAN}

Berdasarkan temuan penelitian ini, dapat disimpulkan bahwa pelanggaran etika jurnalistik Pasal 5 oleh media online nasional terjadi dalam hal: (1) penyebuan identitas korban kejahatan susila berupa, nama asli korban, nama ayah kandung korban (yang bertindak sebagai pelaku kejahatan susila terhadap anaknya sendiri), alamat rumah korban, desa atau kampung/dusun dimana korban tinggal dan menetap, serta alamat dan nama sekolah korban; (2) penyebutan identitas anak pelaku kejahatan dalam berita seperti, pemuatan foto yang menampilkan wajah pelaku dengan jelas pada foto jurnalistik, informasi tentang nama asli pelaku; (3) dari 111 wartawan yang melanggar ketentun Pasal 5 Kode Etik Jurnalistik, dalam penulisan beritanya, sebanyak 13 yang sudah memiliki sertifikasi kompetensi dari Dewan Pers, 65 belum bersertifikat, 33 lainnya tidak terlacak karena menggunakan nama inisial.

\section{UCAPAN TERIMA KASIH}

Ucapan terima kasih tim peneliti Kemristek Dikti RI yang telah memberikan pendanaan dalam skema penelitian Dosen Pemula. Juga kepada Kopertis Wil. III yang telah menjadi fasilitator dalam pelaksanaan hibah penelitian ini, baik sejak ajuan proposal, informasi pendanaan, hingga laporan akhir penelitian ini. Selanjutnya, kami juga menyampaikan terima kasih yang sebesar-besarnya kepada Lembaga Penelitian dan Pengabdian Masyarakat (LPPM) STIKOM Prosia, yang berkenan men-support pelaksanaan penelitian ini, dari mulai tahapan proposal sampai pelaporan final penelitian. Kemudian, ucapan terima kasih juga kami sampaikan kepada rekan-rekan mahasiswa STIKOM Prosia, yang berperan dalam membantu tim peneliti melakukan pengumpulan data, dan pencatatan data coding.

\section{DAFTAR PUSTAKA}

Badan Pengembangan dan Pembinaan Bahasa (Pusat Bahasa). (n.d.). Lacak. Dalam Kamus Besar Bahasa Indonesia (KBBI) Kamus versi online/daring (dalam jaringan). Diperoleh tahun 2020, dari https://kbbi.web.id/lacak-2

Bangun, E. P., Koagouw, F. V. I., \& Kalangi, J. S. (2019). Analisis Isi Unsur Kelengkapan Berita Pada Media Online Manadopost.com. Acta Diurna Komunikasi, 1(3). 
Dewan Pers. (n.d.). Data Perusahan Pers. Dewan Pers. https://dewanpers.or.id/data/perusahaanpers

Dewan Pers. (n.d.). Sertifikasi Wartawan. Dewan Pers. https://dewanpers.or.id/data/sertifikasi_wartawan

Elisabeth M, M., \& Dewi, S. I. (2019) Konstruksi Berita Pemerkosaan Pada Memo-X.com: Edisi Bulan Januari - Fabruari 2016 dan Maret - Mei 2017. JISIP: Jurnal Ilmu Sosial dan Ilmu Politik, 8(2), 1-11.

Fakhri, \& Juanda, H. (2020) Analisis Foto Jurnalistik Pada Kantor Berita Agence France Presse (AFP) Tentang Penerapan Syariat Islam di Aceh Tahun 2017. Jurnal AlBayan: Media Kajian dan Pengembangan Ilmu Dakwah, (26)1, 77-96.

Madonna, M. (2020). Aktualisasi Peran Dewan Pers sebagai Penegak Jurnalisme Independen Terkait Pemberantasan Media Online Abal-Abal. Jurnal Ilmu Komunikasi PROGRESSIO, 1(1), 39-52.

Mahendra, A., \& Harefa, B. (2020). Perlindungan Hukum Terhadap Indentitas Anak sebagai Pelaku Tindak Pidana dalam Proses Peradilan Pidana. Jurnal Kertha Semaya, 8(10), 1629-1649.

Mony, H. (2020). Bahasa Jurnalistik: Aplikasinya dalam Penulisan Karya Jurnalistik di Media Cetak, Televisi, dan Media Online. Deepublish.

Mustofa, A. (2012). Etika Pemberitaan di Televisi (Kasus Pemberitaan Partai Demokrat di TV One dan Metro TV). Jurnal Komunikasi Makna, 3(1), 15-24.

Neuman, W. L. (2013). Metodologi Penelitian Sosial: Pendekatan Kualitatif dan Kuantitatif (7th ed.). Indeks.

Peraturan Dewan Pers Nomor: 6/PERATURAN-DP/V/2008 tentang Pengesahan Surat Keputusan Dewan Pers Nomor 03/SK-DP/III/2006 tentang Kode Etik Jurnalistik.

Setiawan, Y. B. (2011). Analisis Wacana Kritis Pemberitaan Kekerasan Berbasis Gender di Surat Kabar Harian Suara Merdeka. Jurnal Ilmiah Komunikasi Makna, 2(1), 1320 .

Sudibyo, A. (2013). 50 tanya jawab tentang pers: panduan praktis untuk pejabat, politisi, selebritas, pengusaha, dan wartawan. Kepustakaan Populer Gramedia. 
Susilo, D. (2017). Masculinity discourse on media text: A critical review about news about violence on online news portals. Masyarakat, Kebudayaan dan Politik, 30(4), 344352. http://dx.doi.org/10.20473/mkp.V30I42017.344-352

Wijaya, S. H. B., \& Yudiningrum, F. R. (2016). Meningkatkan Kecerdasan Bangsa Melalui Optimalisasi Penerapan Standar Kompetensi. Jurnal Komunikasi (ISKI), 1(2), 97 101. https://doi.org/10.25008/jkiski.v1i2.55

Zamzuardi, Y., \& Syahrul. (2019). Analisis Wacana Kasus Pelecehan Seksual Terhadap Perempuan Pada Berita Online Dalam Perspektif Analisis Sara Mills. Dialektika: Jurnal Bahasa, Sastra, dan Pendidikan Bahasa dan Sastra Indonesia, 6(1), 36-53. http://doi.org/10.15408/dialektika.v6i1.9750 